\title{
Switching from blue to yellow: Altering the spectral properties of a high redox potential laccase by directed evolution
}

Diana M. Matea, Eva Garcia-Ruiz ${ }^{a}$, Susana Camarero ${ }^{b}$, Vladimir V. Shubin ${ }^{c}$, Magnus Falk $^{\mathrm{d}}$, Sergey Shleev ${ }^{\mathrm{d}}$ Antonio O. Ballesterosa and Miguel Alcaldea, ${ }^{*}$

aDepartment of Biocatalysis, Institute of Catalysis, CSIC, 28049 Madrid, Spain; bCentro de Investigaciones Biológicas, CSIC, 28049 Madrid, Spain; cLaboratory of chloroplast biochemistry, A.N. Back Institute of Biochemistry, Russian Academy of Sciences, 119071 Moscow, Russia and dBiomedical Laboratory Science, Faculty of Health and Society, Malmö University, 20506 Malmö, Sweden.

*Corresponding author: Miguel Alcalde. Department of Biocatalysis, Institute of Catalysis, CSIC, Marie Curie 2, 28049, Madrid, Spain. malcalde@icp.csic.es. Phone: +34 915854806, Fax: +34915854760.

Keywords: yellow laccase, blue laccase, directed evolution, a-factor prepro-leader, redox potential, $\mathrm{T} 1 \mathrm{Cu}$ coordinating sphere. 


\section{ABSTRACT}

During directed evolution to functionally express the high redox potential laccase from the PM1 basidiomycete in Saccharomyces cerevisiae (Mate et al. 2010), the characteristic maximum absorption at the $\mathrm{T} 1$ copper site $\left(\mathrm{Abs}_{610} \mathrm{~T} 1 \mathrm{Cu}\right)$ was quenched, switching the typical blue colour of the enzyme to yellow. To determine the molecular basis of this colour change, we characterized the original wild-type laccase and its evolved mutant. Peptide printing and Maldi-TOF analysis confirmed the absence of contaminating protein traces that could mask the $\mathrm{Abs}_{610} \mathrm{~T} 1 \mathrm{Cu}$, while conservation of the redox potential at the $\mathrm{T} 1$ site was demonstrated by spectroelectrochemical redox titrations. Both wild-type and evolved laccases were capable of oxidizing a broad range of substrates (ABTS, guaiacol, DMP, synapic acid) and they displayed similar catalytic efficiencies. The laccase mutant could only oxidize high redox potential dyes (Poly R478, Reactive Black 5, Azure B) in the presence of exogenous mediators, indicating that the yellow enzyme behaves like a blue laccase. The main consequence of over-expressing the mutant laccase was the generation of a six-residue $\mathrm{N}$-terminal acidic extension, which was associated with the failure of the STE13 protease in the Golgi compartment giving rise to alternative processing. Removal of the N-terminal tail had a negative effect on laccase stability, secretion and its kinetics, although the truncated mutant remained yellow. The results of $\mathrm{CD}$ spectra analysis suggested that polyproline helixes were formed during the directed evolution altering spectral properties. Moreover, introducing the A461T and S426N mutations in the T1 environment during the first cycles of laboratory evolution appeared to mediate the alterations to $\mathrm{Abs} 610 \mathrm{~T} 1 \mathrm{Cu}$ by affecting its coordinating sphere. This laccase mutant is a valuable departure point for further protein engineering towards different fates. 
Abbreviations: Abs610 $\mathrm{T} 1 \mathrm{Cu}$, (maximum absorption at the $\mathrm{T} 1$ copper site); $\mathrm{ABTS}$, 2,2`-azino-bis(3-ethylbenzothiazoline-6-sulfonic acid); CD, circular dichroism; DMP, 2,6 dimethoxyphenol; ER, endoplasmic reticulum; $\mathrm{E}^{\mathrm{o}} \mathrm{T} 1$, redox potential at the T1Cu site; HBT, (N-hydroxybenzotriazole); HTP, high-throughput; ICP-OES (Inductively coupled plasma-optical emission spectrometry); IVOE, in vivo overlap extension; MALDI-TOF, matrix assisted laser desorption and ionization-time of flight; MW, molecular weight; pI, isoelectric point; NHE, Normal Hydrogen Electrode; PVDF, (polyvinyldene difluoride); RB5, reactive black 5; $\mathrm{T}_{50}$, temperature at which the enzyme retains $50 \%$ of its activity after a 10 min incubation. 


\section{Introduction}

Fungal laccases (benzenodiol: oxygen oxidoreductase, EC 1.10.3.2) are remarkable biocatalysts with broad substrate specificity and very few requirements (Riva 2006; Rodgers et al. 2010). These enzymes can oxidize a wide range of compounds using oxygen from the air and releasing water as the sole by-product. Fungal laccases oxidize ortho- and para-diphenols, methoxy-substituted phenols, aromatic amines, benzenothiols, hydroxyindols, syringaldazine and some inorganic/organic metal compounds, as well as other molecules (Alcalde 2007). Furthermore, in the presence of redox mediators from natural or synthetic sources, laccases can expand their substrate specificity to oxidize higher redox potential compounds (including non-phenolic substrates such as lignin derivatives, synthetic organic dyes and PAHs) (Cañas \& Camarero 2010). Thus, fungal laccases may have many potential applications in the front line of green chemistry, in the bioremediation of pollutants, the production of $2^{\text {nd }}$ generation biofuels (bioethanol, biobuthanol), the engineering of biosensors and biofuel cells, in the paper, textile and food industries and in the organic synthesis of antibiotics, drugs, cosmetics, polymers and other compounds (Alcalde et al. 2006a; Kunamneni et al. 2007, 2008a, 2008b; Xu 2005). Typically, laccases contain four copper atoms arranged in two highly conserved regions. The reducing substrate binds at the $\mathrm{T} 1 \mathrm{Cu}$ site, while the trinuclear $\mathrm{Cu}$ cluster (containing one $\mathrm{T} 2 \mathrm{Cu}$ and two $\mathrm{T} 3 \mathrm{Cu}$ ) is involved in the binding of molecular oxygen, which is concomitantly reduced to two molecules of water. Upon purification, the paramagnetic $\mathrm{T} 1 \mathrm{Cu}$ (in its oxidized resting state, $\mathrm{Cu}^{2+}$ ) confers the characteristic blue colour of laccase (with an extinction coefficient ranging from 4900 to $5700 \mathrm{M}^{-1} \mathrm{~cm}^{-1}$ at the $\mathrm{Abs}_{610} \mathrm{~T} 1 \mathrm{Cu}$ ) (Davies \& Ducros 2002; Solomon et al. 1996). This particular feature accounts for the name of the bluemulticopper protein group, which is made up of laccases (fungal, bacterial, plant or insect), bacterial copper nitrite reductases, the plant ascorbate oxidases, the 
mammalian plasma proteins ceruloplasmins, and bilirubin oxidases (Alcalde 2007; Baldrian 2006). In addition to blue laccases, several other laccases with distinct spectral characteristics have been described, such as yellow-brown laccases obtained from white-rot fungi under solid-state fermentation conditions. These laccases do not contain $\mathrm{Abs}_{610} \mathrm{~T} 1 \mathrm{Cu}$, supposedly due to the presence of a putative natural mediator derived from lignin biodegradation located at the $\mathrm{T} 1 \mathrm{Cu}$ site (Leontievsky et al. 1997a, 1997b; Pozdnyakova et al. 2004, 2006a). White laccases produced by different basidiomycete strains have also been described with a broad band at around $400 \mathrm{~nm}$ but no absorbance at $610 \mathrm{~nm}$. These white laccases contain two atoms of zinc and one iron/manganese atom, instead of the characteristic trinuclear copper cluster (Haibo et al. 2009; Min et al. 2001; Palmieri et al. 1997). Recently, a unique white laccase containing a single $\mathrm{Cu}$ atom and lacking any other metal content was also reported (Schückel et al. 2011).

Recently, we carried out the directed evolution of a high redox potential laccase from the basidiomycete PM1 to achieve functional heterologous expression in a soluble, stable and active form (Mate et al. 2010). The final variant of this process (OB-1 mutant) was readily secreted by yeast, and it was stable at high temperatures $\left(\mathrm{T}_{50}=73^{\circ} \mathrm{C}\right)$, in the presence of organic co-solvents and over a broad $\mathrm{pH}$ range (3.0 to 9.0$)$. While the evolved laccase retained the general characteristics of the wild-type blue PM1 laccase (Coll et al. 1993), the mutant was yellowbrownish in colour. To further investigate this change in the spectral properties of the enzyme, we performed a comprehensive biochemical and spectroelectrochemical characterization of the evolved and wild-type laccases. 


\section{Material and methods}

\subsection{Materials}

The basidiomycete PM1, originally isolated from a waste-water from a paper factory, was obtained from the Spanish Type Culture Collection (CECT2971). Laccase mutant OB-1 was engineered as described previously (Mate et al. 2010). The laccase from Trametes hirsuta was kindly donated by Prof. A. Yaropolov (Institute of Biochemistry, Moscow, Russia) and the laccase from Trametes versicolor by Prof. Frances H. Arnold (California Institute of Technology [Caltech], Pasadena, CA, USA). The uracil-independent and ampicillin resistant shuttle vector pJRoC30 was also obtained from Caltech (CA, USA). The 2,2'-azino-bis(3ethylbenzothiazoline-6-sulfonic acid) (ABTS), 2,6 dimethoxyphenol (DMP), guaiacol, sinapic acid, Reactive black five (RB5), poly R-478, azure blue (Azure B), Nhydroxybenzotriazole (HBT), acetosyringone, potassium ferrocyanide $\left(\mathrm{K}_{4}\left[\mathrm{Fe}(\mathrm{CN})_{6}\right]\right)$ and potassium cyanomolybdate $\left(\mathrm{K}_{4}\left[\mathrm{Mo}(\mathrm{CN})_{8}\right]\right)$ were all purchased from SigmaAldrich (Madrid, Spain). The E. coli XL2-blue competent cells were obtained from Stratagene (La Jolla, CA, USA) and the protease-deficient S. cerevisiae strain BJ5465 from LGCPromochem (Barcelona, Spain). The zymoprep yeast plasmid miniprep kit, zymoclean gel DNA recovery kit, and the DNA clean and concentrator TM-5 kit were all purchased from Zymo Research (Irvine, CA, USA). The NucleoSpin Plasmid kit was obtained from Macherey-Nagel (Düren, Germany) and the restriction enzymes BamHI and XhoI from New England Biolabs (Hertfordshire, UK). All chemicals were of reagent-grade purity.

\subsection{Culture Media}

Minimal medium contained $100 \mathrm{~mL}$ sterile yeast nitrogen base (6.7\%), 100 $\mathrm{mL}$ sterile yeast synthetic drop-out medium supplement (19.2 g/L) lacking uracil, 
$100 \mathrm{~mL}$ sterile raffinose $(20 \%), 700 \mathrm{~mL} d d \mathrm{H}_{2} \mathrm{O}$ and $1 \mathrm{~mL}$ chloramphenicol $(25 \mathrm{~g} / \mathrm{L})$. Yeast Peptone (YP) medium contained $10 \mathrm{~g}$ yeast extract and $20 \mathrm{~g}$ peptone in 650 $\mathrm{mL} d d \mathrm{H}_{2} \mathrm{O}$. Expression medium contained $720 \mathrm{~mL}$ YP, $67 \mathrm{ml} 1 \mathrm{M} \mathrm{KH}_{2} \mathrm{PO}_{4}$ buffer $(\mathrm{pH}$ 6.0), $111 \mathrm{~mL}$ galactose (20\%), $2 \mathrm{mM} \mathrm{CuSO} 4,25 \mathrm{~g} / \mathrm{L}$ ethanol and $1 \mathrm{ml}$ chloramphenicol $(25 \mathrm{~g} / \mathrm{L})$, made up to $1000 \mathrm{~mL}$ with $d d \mathrm{H}_{2} \mathrm{O}$. YPD solution contained 10 g yeast extract, 20 g peptone, $100 \mathrm{~mL}$ sterile glucose $(20 \%)$ and $1 \mathrm{ml}$ chloramphenicol $(25 \mathrm{~g} / \mathrm{L})$, made up to $1000 \mathrm{~mL}$ with $d d \mathrm{H}_{2} \mathrm{O}$. SC drop-out plates contained $100 \mathrm{~mL}$ sterile yeast nitrogen base $(6.7 \%), 100 \mathrm{~mL}$ sterile yeast synthetic drop-out medium supplement $(19.2 \mathrm{~g} / \mathrm{L})$ lacking uracil, $20 \mathrm{~g}$ bacto agar, $100 \mathrm{~mL}$ sterile glucose $(20 \%)$ and $1 \mathrm{~mL}$ chloramphenicol $(25 \mathrm{~g} / \mathrm{L})$, made up to $1000 \mathrm{~mL}$ with $d d \mathrm{H}_{2} \mathrm{O}$. GAE medium contained (per litre) $10 \mathrm{~g}$ glucose, $1 \mathrm{~g}$ asparagine, $0.5 \mathrm{~g}$ yeast extract, $0.5 \mathrm{~g} \mathrm{~K}_{2} \mathrm{HPO}_{4}, 1 \mathrm{~g} \mathrm{MgSO}_{4} 7 \mathrm{H}_{2} \mathrm{O}$ and $0.01 \mathrm{~g} \mathrm{FeSO}_{4} 7 \mathrm{H}_{2} \mathrm{O}$.

\subsection{Truncated variant (OB-1del mutant)}

The extra $\mathrm{N}$-terminal sequence was removed by deletion mutagenesis using In Vivo Overlap Extension (IVOE, Fig. 5) (Alcalde et al. 2006b; Alcalde 2010). The primers used for PCR 1 were RMLN and ALPHA2 (5' ACCGTTGGAGATGGTGAGGTCTGCGACTGGCCCAATGCTTCTTTTCTCGAGAGATAC CCCTTC 3 , which binds to bp $5-282-345-3^{\prime}$ of pJRoC30-OB-1). The primers for PCR 2 were OB-1MAT (5' AGCATTGGGCCAGTCGCAGAC 3', which binds to bp 5'483-504-3 of pJRoC30-OB-1) and RMLC. The pJRoC30 plasmid was linearized with $\mathrm{XhoI}$ and BamHI, and subsequently, both the linearized plasmid and the PCR products were cleaned, concentrated and loaded onto a low melting point preparative agarose gel for purification using the Zymoclean gel DNA recovery kit (Zymo Research). The linearized plasmid (100 ng) was mixed with the products from PCR1 and PCR 2 (200 ng each) and transformed into competent S. cerevisiae cells. Individual clones were picked and cultured in 96-well plates (GreinerBio-One, 
Frichkenhausen, Germany) containing $50 \mu \mathrm{L}$ of minimal medium per well and screened by the ABTS- procedure as described previously (Mate et al. 2010). Positive clones were re-screened (Mate et al. 2010), and the in vivo repaired plasmid was recovered and the truncated fusion gene confirmed by DNA sequencing.

\subsection{Production and purification of laccases}

\subsubsection{Production of the wild-type laccase in the PM1 basidiomycete (PM1L-wt)}

The PM1 basidiomycete was cultured in GAE medium $(2 \times 50 \mathrm{~mL}$ in $250 \mathrm{~mL}$ flasks) for 5 days at $37^{\circ} \mathrm{C}$ and $240 \mathrm{rev} / \mathrm{min}$, and the pellets from the two flasks were homogenized in distilled water. A $4 \mathrm{~mL}$ suspension of the homogenate was used to inoculate $1 \mathrm{~L}$ flasks containing $300 \mathrm{~mL}$ of GAE medium supplemented with $300 \mu \mathrm{M}$ $\mathrm{CuSO}_{4}$. After 7 days of incubation (maximum laccase activity) the liquid cultures were filtered and the laccase purified.

\subsubsection{Production of the mutant laccase in S. cerevisiae}

A single colony from the $S$. cerevisiae clone containing the mutant laccase gene (OB-1 and OB-1del) was picked from a synthetic complete (SC) drop-out plate, inoculated in $10 \mathrm{ml}$ of minimal medium and incubated for $48 \mathrm{~h}$ at $30^{\circ} \mathrm{C}$ and 225 rpm (Micromagmix shaker, Ovan, Spain). An aliquot of cells was removed, inoculated into a final volume of $50 \mathrm{ml}$ of minimal medium in a $500 \mathrm{ml}$ flask (optical density, $\left.\mathrm{OD}_{600}=0.25\right)$, and incubated for two complete growth phases $(6-8 \mathrm{~h})$. Subsequently, $450 \mathrm{ml}$ of the expression medium was inoculated with the $50 \mathrm{ml}$ preculture in a 2.0-litre baffled flask $\left(\mathrm{OD}_{600}=0.1\right.$ and, after incubating for $70-95 \mathrm{~h}$ at $30^{\circ} \mathrm{C}$ and $225 \mathrm{rpm}$ (maximal laccase activity; $\mathrm{OD}_{600}=25-35$ ), the cells were separated by centrifugation for $15 \mathrm{~min}$ at $6000 \mathrm{rpm}\left(4^{\circ} \mathrm{C}\right.$; Avantin $\mathrm{J}$-E Centrifuge, Beckman Coulter, Fullerton, CA, USA) and the supernatant was double-filtered (through glass followed by a nitrocellulose membrane of $0.45 \mu \mathrm{m}$ pore size). 


\subsubsection{Purification}

Laccases OB-1 and OB-1del were purified by fast protein liquid chromatography (FPLC; LCC-500CI, Amersham Bioscience, Barcelona, Spain) and high performance liquid chromatography (HPLC, Waters 600E System with a PDA detector; Varian, USA). The crude extract was first subjected to fractional precipitation with $55 \%$ ammonium sulphate (first cut) and the pellet removed before subjecting the supernatant to precipitation with $75 \%$ ammonium sulphate (second cut). The final pellet was recovered in $20 \mathrm{mM}$ Bis-Tris buffer (BT buffer, $\mathrm{pH}$ 6.5) and the sample filtered and loaded onto the FPLC, which was coupled to a strong anionic exchange column (HiTraP QFF, Amersham Bioscience) pre-equilibrated with BT buffer. The proteins were eluted with a linear gradient of 0 to $1 \mathrm{M} \mathrm{NaCl}$ in two phases at a flow rate of $1 \mathrm{~mL} / \mathrm{min}$ : from 0 to $50 \%$ over $40 \mathrm{~min}$ and from 50 to $100 \%$ over $10 \mathrm{~min}$. Fractions with laccase activity were pooled, concentrated, dialyzed against BT buffer and further purified by HPLC-PDA coupled with a $10 \mu \mathrm{m}$ high resolution anion exchange Biosuite Q column (Waters, MA, USA) pre-equilibrated with BT buffer. The proteins were eluted using a linear gradient of 0 to $1 \mathrm{M} \mathrm{NaCl}$ at a flow rate of $1 \mathrm{~mL} / \mathrm{min}$ in two phases: from $0-8 \%$ over $60 \mathrm{~min}$ and from $8-100 \%$ over $10 \mathrm{~min}$. The fractions with laccase activity were pooled, dialyzed against 10 $\mathrm{mM}$ Britton and Robinson buffer ( $\mathrm{pH}$ 6.0), concentrated and stored at $-20^{\circ} \mathrm{C}$. Throughout the purification process the fractions were analyzed by SDSpolyacrylamide gel electrophoresis (SDS-PAGE) on 12\% gels in which the proteins were stained with Coomassie brilliant blue (Protoblue Safe, National Diagnostics, GA, USA). All protein concentrations were determined using the Bio-Rad protein reagent (Bio-Rad Laboratories, Hercules, USA) and bovine serum albumin as a standard. For the PM1L-wt the protocol was similar to that used for the laccase mutants in S. cerevisiae, with some minor changes: the pellet from the fractional precipitation was recovered in BT buffer and the sample was filtered and loaded 
onto the FPLC coupled with the HiTrapP QFF column pre-equilibrated with BT buffer. The proteins were eluted with a linear gradient of 0 to $1 \mathrm{M} \mathrm{NaCl}$ in two phases at a flow rate of $1 \mathrm{~mL} / \mathrm{min}$ : from $0-40 \%$ over 40 min and from $40-100 \%$ over $10 \mathrm{~min}$. The fractions with laccase activity were pooled, dialyzed, concentrated and stored at $-20^{\circ} \mathrm{C}$.

\subsection{Estimation of copper content}

The copper content of the purified PM1L-wt and the OB-1 mutant was determined by Inductively Coupled Plasma-Optical Emission Spectrometry (ICPOES), using a Perkin Elmer Optima model 3300 DV spectrometer (Walthman, MA, USA).

\subsection{MALDI-TOF analysis}

Matrix Assisted Laser Desorption and Inonisation Time of Flight (MALDI-TOF) experiments were performed on an Autoflex III MALDI-TOF-TOF instrument (Bruker Daltonics, Bremen, Germany) with a smartbeam laser. The spectra were acquired at a laser power just above the ionization threshold, and the samples were analysed in the positive ion detection and delayed extraction linear mode. Typically, 1000 laser shots were summed into a single mass spectrum. External calibration was performed, using BSA from Bruker, over a range of 30000-70000 Da. The 2,5dihydroxy-acetophenone (2,5-DHAP) matrix solution was prepared by dissolving 7.6 mg (50 umol) in $375 \mu l$ ethanol, to which $125 \mu l$ of $80 \mathrm{mM}$ diammonium hydrogen citrate aqueous solution was added. For sample preparation, $2.0 \mu 1$ of purified enzyme was diluted with $2.0 \mu \mathrm{L}$ of $2 \%$ trifluoro acetic acid aqueous solution and 2.0 $\mu 1$ of matrix solution. A volume of $1.0 \mu \mathrm{L}$ of this mixture was spotted onto the stainless steel target and allowed to dry at room temperature.

\subsection{Protein identification by peptide printing}


The purified OB-1 variant was digested with trypsin at the Proteomic and Genomic Services of the CIB (CSIC, Spain). Peptides were analyzed by MALDI-TOF and further sequenced. Peptides QAILVNDVFPSPLITGNKGDR; GPIVVYDPQDPHKSLYDVDDDSTVITLADWYHLAAK; $\quad$ SINTLNADLAVITVTK; YSFVLNADQDVDNYWIRALPNSGTRNFDGGVNSAILR and SAGSSTYNYANPVYR were compared with the data available from a primary sequence database (Mascot, http://www.matrixscience.com).

\section{8. $p$ I determination}

The $\mathrm{pI}$ of purified laccases ( $8 \mu \mathrm{g}$ of each) was determined by bi-dimensional electrophoresis (Proteomic and Genomic Services, CIB, CSIC, Spain).

\section{9. $N$-terminal analysis}

Purified laccases were resolved by SDS-PAGE and the proteins transferred to polyvinylidene difluoride (PVDF) membranes. The PVDF membranes were stained with Coomassie Brilliant Blue R-250, after which the enzyme bands were cut out and processed for $\mathrm{N}$-terminal amino acid sequencing on a precise sequencer at the Core facilities of the Helmholtz Centre for Infection Research (HZI; Braunschweig, Germany).

\subsection{Kinetics parameters}

As previously reported (Mate et al. 2010), steady-state enzyme kinetics were determined using the following extinction coefficients: ABTS, $\varepsilon_{418}=36000 \mathrm{M}^{-1} \mathrm{~cm}^{-1}$; DMP, $\varepsilon_{469}=27500 \mathrm{M}^{-1} \mathrm{~cm}^{-1}$ (relative to substrate concentration); guaiacol, $\varepsilon_{465}=$ $12100 \mathrm{M}^{-1} \mathrm{~cm}^{-1}$; sinapic acid, $\varepsilon_{512}=14066 \mathrm{M}^{-1} \mathrm{~cm}^{-1}$.

The activity of different laccase variants towards two substrates, potassium ferrocyanide(II), $\mathrm{K}_{4}\left[\mathrm{Fe}(\mathrm{CN})_{6}\right]$ and potassium octacyanomolybdate(IV), $\mathrm{K}_{4}\left[\mathrm{Mo}(\mathrm{CN})_{8}\right]$, 
was determined in homogenous solution by measuring oxygen consumption in a solution with a Clark electrode. . This electrode measures oxygen on a catalytic platinum surface using the net reaction:

$$
\mathrm{O}_{2}+4 \mathrm{e}^{-}+2 \mathrm{H}_{2} \mathrm{O} \rightarrow 4 \mathrm{OH}^{-}
$$

The experiments were performed using the Oxygraph setup (Hansatech Instruments, King's Lynn, UK). All Clark measurements were performed in $50 \mathrm{mM}$ acetate buffer ( $\mathrm{pH} 4.0)$. For comparison, the activity of the Trametes hirsuta laccase (ThL), $\mathrm{E}^{\mathrm{o}^{-}}, \mathrm{T} 1780 \mathrm{mV}$ ) was also determined, and laccase activities were determined using at substrate concentrations of $10 \mathrm{mM}$ for $\mathrm{K}_{4}\left[\mathrm{Fe}(\mathrm{CN})_{6}\right]$ and $20 \mathrm{mM}$ for $\mathrm{K}_{4}\left[\mathrm{Mo}(\mathrm{CN})_{8}\right]$, allowing each enzyme to reach its maximal catalytic rates.

\subsection{Determination of thermostability}

The thermostability of the different laccase samples was estimated by assessing their $\mathrm{T}_{50}$ values using $96 / 384$ well gradient thermocyclers. Appropriate laccase dilutions were prepared, such that $20 \mu \mathrm{L}$ aliquots produced a linear response in the kinetic mode. Subsequently, $50 \mu \mathrm{L}$ samples were assessed at each point in the gradient scale and a temperature gradient profile ranging from 35 to $90^{\circ} \mathrm{C}$ was established as follows (in ${ }^{\circ} \mathrm{C}$ ): $35.0,36.7,39.8,44.2,50.2,54.9,58.0$, $60.0,61.1,63.0,65.6,69.2,72.1,73.9,75.0,76.2,78.0,80.7,84.3,87.1,89.0$ and 90.0. After a $10 \mathrm{~min}$ incubation, the samples were chilled on ice for $10 \mathrm{~min}$ and further incubated at room temperature for $5 \mathrm{~min}$. Next, $20 \mu \mathrm{L}$ of samples were subjected to the same ABTS-based colorimetric assay described above. Thermostability values were deduced from the ratio between the residual activities incubated at different temperature points and the initial activity at room temperature (Garcia-Ruiz et al. 2010). 


\subsection{Electrochemical characterization}

Spectroelectrochemical analysis of PM1L-wt and the OB-1 mutant, as well as the Trametes hirsuta laccase (ThL), was performed as described previously (Larsson et al. 2001) using a micro-spectroelectrochemical cell with a gold capillary electrode. The potential of the gold capillary in the cell was controlled by a three-electrode BAS LC-3E potentiostat from Bioanalytical Systems (BAS, West Lafayette, IN, USA) using an $\mathrm{Ag}|\mathrm{AgCl}| \mathrm{KCl}$ reference electrode (BAS) and a platinum counter electrode. The absorbance spectra were monitored with a PC2000-UV-VIS miniature fibre optic spectrometer (Ocean Optics; Dunedin, FL, USA) with an effective range of 200$1100 \mathrm{~nm}$. The redox potential of the $\mathrm{T} 1$ site of the enzymes was determined by mediated spectroelectrochemical redox titration (MRT). A complex mediator system containing two different mediators, $\mathrm{K}_{4}\left[\mathrm{Fe}(\mathrm{CN})_{6}\right]$ and $\mathrm{K}_{4}\left[\mathrm{~W}(\mathrm{CN})_{8}\right.$, with formal redox potentials of $430 \mathrm{mV}$ and $780 \mathrm{mV}$, respectively, against $\mathrm{NHE}$ (normal hydrogen electrode), was used for the MRT in accordance with previously published methods (Christenson et al. 2006).

\subsection{Circular dichroism spectra}

CD spectra were recorded with a Chirascan ${ }^{\mathrm{TM}} \mathrm{CD}$ Spectrometer (Applied Photophysics, Leatherhead, UK). The measurements were performed under an atmosphere of $\mathrm{N}_{2}$ with a $1 \mathrm{~mm}$ light path quartz cell (Hellma, Müllheim, Germany) using protein concentrations in the range from 0.05 up to $0.1 \mathrm{mg} / \mathrm{ml}$. The protein concentration was determined in accordance with methodology presented in (Scopes 1974). The parameters of the secondary structures were calculated using an in house program ("Protein-CD v 1.5"; Moscow, Russia), as described previously (Shleev et al. 2006). This software uses a ridge regression procedure in the method of linear regression and allows creation of the optimal selection from CD spectra in a database for mathematical treatment of a CD spectrum of interest. As known from 
X-ray studies of redox enzymes from different sources laccases are $\beta$-structured proteins. Indeed, the $\mathrm{CD}$ database for our calculations contained only $\beta$-proteins. From $39 \beta$-proteins only 25 examples were selected based on the criterion of rootmean-square similarities of their spectra with a CD spectrum of a wild-type laccase from Coprinus cinereus. For the learning sample containing 25 proteins regression coefficients were obtained, which were used in the calculation of basic elements of protein secondary structures, viz. $a$-helix, $3_{10}$-helix, $\beta$-structure, $\beta$-turns, and random (unordered) structure. In order to determine calculating errors the learning sample was tested by alternated removal of each protein from the database.

\subsection{DNA sequencing}

The plasmid containing the OB-1del gene was sequenced with an ABI 3730 DNA Analyzer-Applied Biosystems Automatic Sequencer from Secugen (CIB, Madrid). The following primers, designed using Fast-PCR software (University of Helsinki, Finland), were used: RMLN; PM1FS (5'ACGACTTCCAGGTCCCTGACCAAGC-3'); $\quad$ PM1RS TCAATGTCCGCGTTCGCAGGGA -3') and RMLC.

\subsection{Protein Modelling}

The Protein Data Bank was searched for proteins with known structural homology to the PM1 laccase. The protein with the highest sequence similarity to PM1 was the laccase from Trametes trogii, the crystal structure of which was solved at a resolution of $1.58 \AA$ and it exhibits 97\% sequence identity to PM1 (PDB id: 2hrgA) (Matera et al. 2008). A model was generated using the Swiss-Model protein automated modelling server (http://swissmodel.expasy.org/), and analyzed using DeepView/Swiss-Pdb Viewer and PyMol Viewer. 


\section{Results and discussion}

\subsection{The yellow $O B-1$ mutant}

The blue laccase from basidiomycete PM1 belongs to a group of high redox potential laccases discovered in the western Mediterranean region, which includes laccases from other white-rot fungi (Trametes troggi, Trametes C30, Coriolopsis gallica and Pycnoporus cinnabarinus) (Colao et al. 2006). These laccases share sequence identity of at least $\sim 75 \%$ and they have been characterized as blue laccases, i.e.: with a copper content of 4 atoms per protein; displaying a shoulder at approximately $330 \mathrm{~nm}$ corresponding to the type III binuclear copper couple; and a peak at $610 \mathrm{~nm}$ associated with $\mathrm{T} 1 \mathrm{Cu}$, also known as blue copper. We previously modified the PM1 laccase through eight rounds of directed evolution and screening, to achieve functional expression in S. cerevisiae (Mate et al. 2010). In that study, a fusion gene comprising the a-factor prepro-leader and the mature PM1 laccase was constructed and improved by consecutive cycles of random mutagenesis, DNA recombination and semi-rational approaches, to generate the final OB-1 mutant that harboured a full set of coppers (estimated by ICP-OES, see Experimental Procedures). However, unlike the wild-type laccase produced by basidiomycete PM1 (PM1L-wt), the OB-1 mutant did not display the characteristic laccase absorption spectrum, but rather one similar to that of the yellow laccases (Fig. 1A). The $A_{280} / A_{610}$ ratio represents the combined absorbances of tryptophan and aromatic residues at $280 \mathrm{~nm}$, divided by the absorbance of $\mathrm{T} 1 \mathrm{Cu}$ at $610 \mathrm{~nm}$. Generally, blue laccases exhibit an $A_{280} / A_{610}$ ratio of $\sim 20$, while that of the yellow laccases ranges from 90 to 150 (Leontievsky et al. 1997a; Pozdnyakova et al. 2006a). Thus, the PM1L-wt is a blue-laccase, while the OB-1 mutant can be considered as yellow laccase, based on its $\mathrm{T} 1 \mathrm{Cu}$ spectral features (Table 1). OB-1 was purified to homogeneity (purification factor $\sim 115$; Table 2, Fig. 1B) to rule any possible 
contamination by other residual proteins that could mask absorbance at $610 \mathrm{~nm}$. Subsequently, the purified mutant was analysed by MALDI-TOF mass spectrometry, which revealed a single peak for the mono- and di-protonated species, indicating a high level of purity in the preparation (Fig. 1C). The purified OB-1 was then identified by peptide printing, resulting in a protein score of 480 , matching that of the original PM1 laccase (accession number: CAA78144 GI:58324).

\subsection{Biochemical characterization}

Both laccases had similar isoelectric points and $\mathrm{pH}$ activity profiles for ABTS and DMP (see Table 1 for a summary of the main characteristics of PM1L-wt and the OB-1 mutant, and Fig. 1D, E, F), although the degree of glycosylation differed, as might be expected for enzymes produced in different hosts (Table 1). The kinetic parameters were assessed using different phenolic and non-phenolic compounds. It was not possible to characterize native PM1 laccase produced in S. cerevisiae due to its poor secretion (0.035 ABTS-units/litre of supernatant). The $k_{\text {cat }}$ of the OB-1 variant was close to that of PM1L-wt produced from the fungal strain (Table 3). Bearing in mind that the total activity of PM1 laccase was enhanced round after round of evolution, our data indicate that the $k_{\text {cat }}$ of the native laccase PM 1 must be several fold lower when the enzyme is expressed in S. cerevisiae than in the original host. Our results agreed well with those for other laccases expressed in $S$. cerevisiae. For example, when the low redox potential laccase from Myceliophthora thermophila was functionally expressed in yeast, the $k_{\text {cat }}$ of the enzyme decreased 10-fold in the S. cerevisiae expression system (Bulter et al. 2003).

\subsection{Laccase mediator system}

Redox mediators are small synthetic or natural molecules that can act as diffusible electron carriers. After oxidization by laccases, the mediator oxidizes the 
target substrate through non-enzymatic mechanisms (Baiocco et al. 2003; Cañas \& Camarero 2010). Laccase-mediator systems have been exhaustively investigated, as they permit the oxidation of high redox potential compounds that cannot be oxidized by laccases alone (including lignin derivatives, recalcitrant dyes and PAHs) (Morozova et al. 2007). Some fungal laccases produced in solid-phase cultures are yellow rather than the typical blue colour exhibited by the same laccases when produced in liquid cultures (Leontievsky et al. 1997a, 1997b; Pozdnyakova et al. 2004, 2006a). In solid state fermentation of white-rot fungi using lignocellulosic materials (e.g., wheat straw containing lignin), a natural lignin-derived compound can modify the $\mathrm{T} 1 \mathrm{Cu}$, switching from the oxidized resting state $\left(\mathrm{Cu}^{2+}\right)$ to the reduced state $\left(\mathrm{Cu}^{1+}\right)$, and thus quenching the $\mathrm{Abs}_{610} \mathrm{~T} 1 \mathrm{Cu}$. Interestingly, once laccase binds to this natural and hitherto unknown molecule, the enzyme can oxidize higher redox potential compounds without the need for any exogenous mediator (Leontievsky et al. 1997b; Pozdnyakova et al. 2004, 2006b; RodakiewiczNowak et al. 1999). The presence of this putative "endogenous mediator" bound to the $\mathrm{T} 1 \mathrm{Cu}$ site in yellow laccases is one of the characteristic features of these enzymes. Although the OB-1 mutant was produced in conventional YP liquid media, the possible binding of a mediator that altered the $\mathrm{Abs} 610 \mathrm{~T} 1 \mathrm{Cu}$ cannot be ruled out. We analyzed the oxidation of several high redox potential dyes by the OB-1 mutant in the presence or absence of exogenous mediators (the artificial mediator HBT or the natural mediator acetosyringone, Fig. 2A). RB5, PolyR478 and Azure B were only oxidized efficiently in the presence of the mediator, with the best yields produced by the HBT-laccase system. Unlike all the yellow laccases described in literature, the OB-1 mutant oxidized none of the recalcitrant dyes in the absence of exogenous mediators. Similar results were obtained for the blue laccase from Trametes versicolor (TvL), confirming that the yellow OB-1 mutant behaves like a blue laccase in terms of its laccase-mediator requirements (Fig. 2B). 


\subsection{Spectro-electrochemical characterization}

To determine whether modification of the $\mathrm{Abs}_{610} \mathrm{~T} 1 \mathrm{Cu}$ affects the laccase redox potential, midpoint potentials were measured for PM1L-wt and the OB-1 mutant to provide an estimate of the potential value of the $\mathrm{T} 1 \mathrm{Cu}$ site $\left(\mathrm{E}^{\mathrm{o}} \mathrm{T} 1\right)$. The $\mathrm{E}^{\mathrm{o}-\mathrm{T}} 1 \mathrm{Cu}$ for PM1L-wt was $+760 \mathrm{mV}$ when compared to NHE from the mediated reductive redox titration, placing the PM1 laccase in the group of high redox potential laccases (Fig. 3A). It was not possible to accurately estimate the $\mathrm{E}^{\mathrm{o}^{`} \mathrm{~T} 1 \mathrm{Cu}}$ for the OB-1 mutant as the quenched signal at $610 \mathrm{~nm}$ prevented calculation of a reliable value. However, a constant increment was detected with increasing voltage (from $+350 \mathrm{mV}$ to $+950 \mathrm{mV}$ ), indicating reduction of the $\mathrm{T} 1 \mathrm{Cu}$ (Fig. 3B). The redox potential of the T1 site was also assessed in an activity assay based on the consumption of $\mathrm{O}_{2}$ by the laccase. In all cases, activities with the $\mathrm{K}_{4}\left[\mathrm{Fe}(\mathrm{CN})_{6}\right] / \mathrm{K}_{4}\left[\mathrm{Mo}(\mathrm{CN})_{8}\right]$ pair fell within the same range $(196 \pm 12,150 \pm 3,195 \pm 8$ $\mathrm{s}^{-1}$ for ThL, PM1L-wt and OB-1, respectively) indicating that the redox potential of the OB-1 mutant was, in all likelihood, unaltered after evolution (Fig. 3C).

The CD spectrum of the PM1L-wt (Fig. 3D) was very similar to those of Trametes hirsuta, Coprinus cinereus and other fungal laccases (Schneider et al. 1999; Shleev et al. 2004). The calculated basic elements of the secondary structure of the wild-type enzyme correlated well with the content of $\mathrm{a}$-helix, $3_{10}$-helix, $\beta$ structure, $\beta$-turns, and unordered structures in Coprinus cinereus laccase obtained from X-ray analysis (Table 4). CD spectra of mutants, however, differed significantly from the spectrum of the wild-type enzyme, viz. intensive negative band in the region of $200 \mathrm{~nm}$ occurred, which is a very distinguishing feature for proteins with irregular structures, such as collagens and polyproline helixes (Sreeram \& Woody 1994). In the frame of the calculation method used in our studies, this difference in CD spectra of mutants compared to the wild type laccase is described by the 
percentage increase of irregular (unordered) structure with concomitant small decrease in regular structures, viz. a-helix, $\beta$-structure, and $\beta$-turns. It is important to emphasize that a positive band in the region of $224 \mathrm{~nm}$ do exist on CD spectra of mutants, also characteristic of polyproline helix structures. (Sreeram \& Woody 1994). Usually, polyproline helixes are short (only 3-6 amino acids) and they are classified as an unordered structure (Mansiaux et al. 2011). Moreover, the specific ellipticity of polyproline helixes varies from 45000 up to 100000 degr .cm² $\mathrm{dmol}^{-1}$ (Sreeram \& Woody 1994). Since the specific ellipticity for mutants of laccase in the region of polyproline helix (ca. $200 \mathrm{~nm}$ ) was calculated to be 9000-12 000 degr. $\mathrm{cm}^{2} \mathrm{dmol}^{-1}$ (Fig. 3D), it can be suggested that the observed spectral changes might be related to the transition of $15-30 \%$ amino acids into polyproline helix (poly(Pro)II helix and the poly(Pro)II-type) during the direct evolution of the wild-type laccase.

\subsection{OB-1 truncated variant}

The OB-1 mutant was engineered by constructing of a fusion protein harbouring the a-factor prepro-leader from $S$. cerevisiae and the native mature laccase PM1. After screening over 50,000 clones in eight cycles of directed evolution, the OB-1 mutant contained the following mutations: V[a10]D, N[a23]K, G(a62)G, A[a87]T, $\underline{\mathrm{E}(\mathrm{a} 90) \mathrm{E}}$ Q Q70Q, V162A, $\underline{\mathrm{A} 167 \mathrm{~A}}, \mathrm{H} 208 \mathrm{Y}, \mathrm{S} 224 \mathrm{G}, \mathrm{A} 239 \mathrm{P}, \mathrm{D} 281 \mathrm{E}$, S426N, L456L, A461T (synonymous mutations are underlined and brackets denote mutations in the a-factor pre-proleader). Mutations in the hydrophobic core of the evolved a-factor prepro-leader enhanced functional expression, whereas some mutations in the mature protein improved catalytic efficiency, folding and secretion by altering the interactions with the surrounding residues (Mate et al. 2010).

The a-factor pro-leader is thought to be involved in vacuolar targeting and chaperone like-activity, and it is processed at the Golgi through the action of three 
proteases; KEX2, STE13 and KEX1. KEX2 is a membrane-bound endoproteinase that cleaves the carboxyl side of the Lys-Arg motif. Maturation is sustained by the action of STE13, a membrane-bound dipeptidyl aminopeptidase that removes Glu/Asp-Ala dipeptides from the N-terminus of the mature protein. Finally, the serine protease KEX1 removes the Lys and Arg residues from the C-terminus, which is essential for the proper maturation of a-factor tandems but is not necessary for the heterologous expression of a-factor prepro-leader fusion proteins. Several studies have described incorrect processing in response to high levels of secreted proteins produced from fusion genes with the a-factor prepro-leader, ultimately resulting in extracellular proteins containing a spacer dipeptide sequence linked to the N-terminus (Romanos et al. 1992). This effect is thought to reflect to the low levels of STE13 protease produced by yeast, insufficient to process the high levels of heterologous proteins expressed by these synthetic genes. When we sequenced the $\mathrm{N}$-terminal end of the OB-1 mutant, an extra acidic N-terminal extension (ETEAEF) led the original mature protein, confirming that STE13 fails to process the proleader (Fig. 4A). ETEA is the spacer dipeptide for STE13 (including mutation $\mathrm{A}[\mathrm{a} 87] \mathrm{T})$, whereas the $\mathrm{EF}$ dipeptide was introduced during the cloning strategy to fuse the a-factor prepro-leader to the mature OB-1. To determine the effect of this alternative processing on laccase characteristics (including the $\mathrm{Abs}_{610} \mathrm{~T} 1 \mathrm{Cu}$ spectral properties, stability and kinetics), we deleted the portion of our evolved gene encoding the acidic tail. Accordingly, a truncated version of the OB-1 mutant (OB1del) was engineered by deletion mutagenesis through IVOE (Fig. 5). The new variant was produced, purified and $\mathrm{N}$-terminal sequenced, confirming the corrected processing and secretion in the absence of STE13 cleavage (i.e., through KEX2 protease activity only, Fig. 4B). The OB-1del mutant was a similar yellow colour to OB-1 and moreover, the truncated version had an Abs280/Abs610 ratio of $\sim 160$ (Fig. 1A, Table 1). The pI shifted from 5.1 to 5.3 due to the loss of three acidic 
residues upon deletion. The removal of the acidic tail of the OB-1del mutant did not have associated significant changes in the CD spectra (Fig. 3D, Table 4). The OB1del mutant had the same $\mathrm{pH}$ activity profile as OB-1 (Fig.1D, E), although it was less stable (with a $\mathrm{T}_{50} 1.4^{\circ} \mathrm{C}$ less than that of OB-1, Fig.1F) and with worse kinetics (with $k_{\text {cat }} / K_{m} 3$ to 1.3 -fold lower than that of OB-1; Table 3). Finally, the truncated version was expressed more weakly in yeast (secretion dropped by $~ 40 \%$ ). Removal of the charged spacer peptide made the fusion directly linked to the Lys-Arg processing site a poor substrate for the KEX2 protease, indicating the importance of an acidic environment in the proximity of the KEX2 cleavage site for secretion. This same effect was also observed for the a-factor leader-interferon-a1, which accumulated intracellularly and of which unprocessed and partially processed forms was secreted (Zsebo et al. 1986), as well as in our laboratory during the directed evolution of a versatile peroxidase from Pleurotus eryngii (Garcia-Ruiz et al. 2012).

\subsection{Modification of the coordination sphere of the T1 Cu site}

Despite the absence of $\mathrm{Abs}_{610} \mathrm{~T} 1 \mathrm{Cu}$, the yellow OB-1 mutant exhibited the primary biochemical features of a blue laccase. Given that the extra N-terminal extension was not responsible for the colour change, we could attribute the spectral changes to the polyproline helixes detected by CD. Moreover, some of the new amino acid changes induced by directed evolution in the mature OB-1 mutant may modify the $\mathrm{T} 1 \mathrm{Cu}$ environment. The mutant protein harbours seven beneficial mutations (V162A, H208Y, S224G, A239P, D281E, S426N, A461T), which were mapped in a 3D-structure model based on the crystal structure of the Trametes trogii laccase (97\% identity). These beneficial mutations were at a distance of 8 to $40 \AA$ of the $\mathrm{T} 1 \mathrm{Cu}$ site. The $\mathrm{Cu} \mathrm{T} 1$ is trigonally coordinated to two His residues (His455 and His394, according to PM1 numbering) and Cys450. In PM1L-wt, the 
Abs610 T1Cu results from a covalent copper-cysteine bond (Davies \& Ducros 2002). Interestingly, mutations $\mathrm{A} 461 \mathrm{~T}$ and $\mathrm{S} 426 \mathrm{~N}$ are located near the $\mathrm{T} 1 \mathrm{Cu}$ site and may alter the coordination of the blue copper (Fig. 6). According to our model, the A461T mutation $(8.86 \AA \AA$ from $\mathrm{T} 1 \mathrm{Cu})$ appears to establish a new $\mathrm{H}$-bond with Phe460, which in turn is bound to the coordinating Cys450. It is likely that this change affects the overall geometry of the $\mathrm{T} 1 \mathrm{Cu}$ and hence, the $\mathrm{Abs} 610 \mathrm{~T} 1 \mathrm{Cu}$, as the highly covalent $\mathrm{Cu}-\mathrm{S}(\mathrm{Cys})$ bond is responsible for the pronounced blue colour of laccases. The $\mathrm{S} 426 \mathrm{~N}$ mutation (at $8.23 \AA$ from $\mathrm{T} 1 \mathrm{Cu}$ ) appears to break one H-bond with Gly428, while establishing a new H-bond with the adjacent Thr427. The T1 Cu ligand His394 is bound to Thr427 and thus, the newly established H-bond may alter the coordinating sphere of the $\mathrm{T} 1 \mathrm{Cu}$. Reversal of these mutations may in turn reverse the effects on $\mathrm{Abs}_{610} \mathrm{~T} 1 \mathrm{Cu}$, albeit at the cost of expression. In fact, when the A461T and S426N mutations were introduced in the second cycle of evolution, their subsequent removal jeopardized the stability and secretion of the entire protein, hindering the production of the mutant (Mate et al. 2010).

\section{Conclusions}

The OB-1 mutant is a high redox potential laccase with specific spectral features derived from the presence of polyproline helixes together with modifications in $\mathrm{T} 1 \mathrm{Cu}$ coordinating sphere. The alterations in absorbance at the $\mathrm{T} 1 \mathrm{Cu}$ site observed in this mutant indicate that not all yellow laccases necessarily contain an endogenous mediator bound to the $\mathrm{T} 1 \mathrm{Cu}$ site, and more significantly, that not all yellow laccases are produced from solid state cultures, but they can also be obtained as genetically modified products. The yellow laccase OB-1 displays similar characteristics to the blue PM1L-wt laccase, in terms of kinetics, redox potential, laccase mediator requirements, $\mathrm{pH}$ profile and stability. This mutant contains an extra acidic N-terminal tail, which is involved in alternative processing and folding, 
and that facilitates laccase secretion as an active, soluble and stable form. Thus, this mutant would appear to be a suitable vehicle for directed evolution experiments towards challenging destinies (from bioremediation to novel green processes) (Mate et al. 2011).

\section{Acknowledgements}

We thank Dr Francisco J. Plou from the Institute of Catalysis (CSIC, Spain) for assistance with the HPLC purification. This study was based on work funded by EU Project FP7 (3D-Nanobiodevice, NMP4-SL-2009-229255), COST Action CM0701, Swedish Research Council (2009-3266) and the Spanish National project (Evofacel, BIO2010-19697). D.M.M. was supported by a JAE fellowship (CSIC) and E.G.R by a 3D-Nanobiodevices contract.

\section{Declaration of interest}

The authors report no conflicts of interest. The authors alone are responsible for the content and writing of the paper.

\section{References}

Alcalde M, Ferrer M, Plou FJ, Ballesteros A. 2006a. Environmental biocatalysis: from remediation with enzymes to novel green processes. Trends Biotechnol 24:281287. 
Alcalde M, Zumárraga M, Polaina J, Ballesteros A, Plou FJ. 2006b. Combinatorial saturation mutagenesis by in vivo overlap extension for the engineering of fungal laccases. Comb Chem and High T Scr 9:719-727.

Alcalde M. 2007. Laccase: biological functions, molecular structure and industrial applications. In: Polaina J, MacCabe AP, Editors. Industrial Enzymes: Structure, Function and Applications. Dordrecht: Springer. pp. 459-474.

Alcalde M. 2010. Mutagenesis protocols in Saccharomyces cerevisiae by in vivo overlap extension. In: Bramman J, Editor. In vitro Mutagenesis Protocols. Methods in Molecular Biology. Totowa: Humana Press. pp. 3-14.

Baiocco P, Barreca AM, Fabbrini M, Galli C, Gentili P. 2003. Promoting laccase activity towards non-phenolic substrates: a mechanistic investigation with some laccase-mediator systems. Org Biomol Chem 1:191-197.

Baldrian P. 2006. Fungal laccases-occurrence and properties. FEMS Microbiol Rev $30: 215-242$

Brake AJ. 1990. Alpha-Factor Leader-Directed Secretion of Heterologous Proteins from Yeast. Method Enzymol 185:408-421.

Bulter T, Alcalde M, Sieber V, Meinhold P, Schlachtbauer C, Arnold FH. 2003. Functional expression of a fungal laccase in Saccharomyces cerevisiae by directed evolution. Appl Environ Microb 69:987-995.

Cañas AI, Camarero S. 2010. Laccases and their natural mediators: biotechnological tools for sustainable eco-friendly processes. Biotechnol Adv 28:694-705. 
Christenson A, Shleev S, Mano N, Heller A, Gorton L. 2006. Redox potentials of the blue copper sites of bilirubin oxidases. Biochim Biophys Acta 1757:1634-1641.

Colao M, Lupino CS, Garzillo AM, Buonocore V, Ruzzi M. 2006. Heterologous expression of lccl gene from Trametes trogii in Pichia pastoris and characterization of the recombinant enzyme. Microb Cell Fact 5:31.

Coll PM, Fernandez-Abalos JM, Villanueva JR, Santamaria R, Perez P. 1993. Purification and characterization of a phenoloxidase (laccase) from the lignindegrading basidiomycete PM1 (CECT 2971). Appl Environ Microb 59:2607-2613.

Davies GJ, Ducros V. 2002. Laccase. In: Messerschmidt WA, Huber R, Wieghardt K, Poulos T, Editors. Handbook of metalloproteins. New York: John Wiley \& Sons. pp. 1359-1368.

Garcia-Ruiz E, Mate D, Ballesteros A, Martinez AT, Alcalde M. 2010. Evolving thermostability in mutant libraries of ligninolytic oxidoreductases expressed in yeast. Microb Cell Fact 9:17.

Garcia-Ruiz E., Gonzalez-Perez D, Ruiz-Dueñas FJ, Martinez AT, Alcalde M. 2012. Directed evolution of a temperature, peroxide and alkaline $\mathrm{pH}$ tolerant versatile peroxidase. Biochem J 441:487-498.

Haibo Z, Yinglong Z, Feng H, Peiji G, Jiachuan C. 2009. Purification and characterization of a thermostable laccase with unique oxidative characteristics from Trametes hirsuta. Biotechnol Lett 31:837-843.

Kunamneni A, Ballesteros A, Plou FJ, Alcalde M. 2007. Fungal laccase: a versatile enzyme for biotechnological applications. In: Mendez-Vilas A, Editor. Communicating Current Research and Educational Topics and Trends in Applied Microbiology. Badajoz: Formatex Publishers. pp. 233-245. 
Kunamneni A, Camarero S, García C, Plou FJ, Ballesteros A, Alcalde M. 2008a. Engineering and applications of fungal laccases for organic synthesis. Microb Cell Fact $7: 1-17$.

Kunamneni A, Plou FJ, Ballesteros A, Alcalde M. 2008b. Laccase and their applications: a patent review. Recent Pat Biotechnol 2:10-24.

Larsson T, Lindgren A, Ruzgas T. 2001. Spectroelectrochemical study of cellobiose dehydrogenase and diaphorase in a thiol-modified gold capillary in the absence of mediators. Bioelectrochemistry 53:243-249.

Leontievsky AA, Vares T, Lankinen P, Shergill JK, Pozdnyakova NN, Myasoedova NM, Kalkkinen N, Golovleva LA, Cammac R, Thurston CF, Hatakka A. 1997a. Blue and yellow laccases of ligninolytic fungi. FEMS Microbiol Lett 156:9-14.

Leontievsky A, Myasoedova N, Pozdnyakova N, Golovleva L. 1997b. 'Yellow' laccase of Panus tigrinus oxidizes non-phenolic substrates without electron-transfer mediators. FEBS Lett 413:446-448.

Mansiaux Y, Joseph AP, Gelly JC, de Breven AG. 2011. Assignment of PolyProline II conformation and analysis of sequence-structure relationship. PLoS One 6:e18401.

Mate D, Garcia-Burgos C, Garcia-Ruiz E, Ballesteros AO, Camarero S, Alcalde M. 2010. Laboratory Evolution of High-Redox Potential Laccases. Chem Biol 17:10301041

Mate D, Garcia-Ruiz E, Camarero S, Alcalde M. 2011. Directed evolution of fungal laccases. Curr Genomics 12:113-122. 
Matera IA, Gullotto S, Tilli M, Ferraroni A, Scozzafava A, Briganti F. 2008. Crystal structure of the blue multicopper oxidase from the white-rot fungus Trametes trogii complexed with p-toluate. Inorg Chim Acta 361:4129-4137.

Min KL, Kim YH, Kim YW, Jung HS, Hah YC. 2001. Characterization of a novel laccase produced by the wood-rotting fungus Phellinus ribis. Arch Biochem Biophys 392:279-286.

Morozova OV, Shumakovich GP, Shleev SV, Yaropolov YI. 2007. Laccase-mediator systems and their applications: A review. Appl Biochem Microbiol 43:523-535.

Palmieri G, Giardina P, Bianco C, Scaloni A, Capasso A, Sannia G. 1997. A novel white laccase from Pleurotus ostreatus. J Biol Chem 272:31301-31307.

Pozdnyakova NN, Rodakiewicz-Nowak J, Turkovskaya OV. 2004. Catalytic properties of yellow laccase from Pleurotus ostreatus D1. J Mol Catal B-Enzym 30:19-24.

Pozdnyakova NN, Turkovskaya OV, Yudina EN, Rodakiewicz-Nowak Y. 2006a. Yellow laccase from the fungus Pleurotus ostreatus D1: Purification and characterization. Appl Biochem Microbiol 42:56-61.

Pozdnyakova N.N., Rodakiewicz-Nowak J., Turkovskaya O.V., Haber J. 2006b. Oxidative degradation of polyaromatic hydrocarbons and their derivatives catalyzed directly by the yellow laccase from Pleurotus ostreatus D1. J Mol Catal B:Enzym 41:8-15.

Riva S. 2006. Laccases: blue enzymes for green chemistry. Trends Biotechnol 24:219-226. 
Rodakiewicz-Nowak J, Haber J, Pozdnyakova N, Leontievsky A, Golovleva LA. 1999. Effect of ethanol on enzymatic activity of fungal laccases. Bioscience Rep 19:589600.

Rodgers CJ, Blandford CF, Giddens SR, Skamnioti P, Armstrong FA, Gurr SJ. 2010. Designer laccases: a vogue for high-potential fungal enzymes?. Trends Biotechnol 28:63-72.

Romanos MA, Scorer CA, Clare JJ. 1992. Foreign gene expression in yeast: a review. Yeast 8:423-488.

Schneider PM, Caspersen B, Mondorf K, Halkier T, Skov LK, Ostergaard PR, Brow KM, Brown SH, Xu F. 1999. Characterization of a Coprinus cinereus laccase. Enz Microb Technol 25:502-508.

Schückel J, Matura A, van Pée KH. 2011. One-copper laccase-related enzyme from Marasmius sp.: Purification, characterization and bleaching of textile dyes. Enzyme Microb Technol 48:278-284.

Scopes RK. 1974. Measurements of protein by spectrophotometry at $205 \mathrm{~nm}$. Anal Biochem 59:277-282.

Shleev SV, Morozova O, Nikitina O, Gorshina ES, Rusinova T, Serezhenkov VA, Burbaev DS, Gazaryan IG, Yaropolov AI. 2004. Comparison of physico-chemical characteristics of four laccases from different basidiomycetes. Biochimie 86:693703.

Shleev S, Shumakovic GP, Nikitina O, Morozova IV, Pavlishko HM, Gayda GZ, Gonchar MV. 2006. Purification and characterization of alcohol oxidase from a genetically constructed over producing strain of the methylotrophic yeast Hansenula polymorpha. Biochemistry-Moscow 71:245-250. 
Shuster JR. 1991. Gene expression in yeast: protein secretion. Curr Opin Biotechnol 2:685-690.

Solomon EI, Sundaram UM, Machonkin TE. 1996. Multicopper oxidases and oxygenases. Chem Rev 96:2563-2605.

Sreeram N, Woody RW. 1994. Poly(Pro)II helixes in globular proteins: Identification and circular dichroic analysis. Biochemistry 33:10022-10025.

Xu F. 2005. Applications of oxidoreductases: recent progress. Ind Biotechnol 1:3850.

Zsebo KM, Lu HS, Fieschko JC, Goldstein L, Davis J, Duker K, Suggs SV, Lai PH, Bitter GA. 1986. Protein secretion from Saccharomyces cerevisiae directed by the prepro-a-factor leader region. J Biol Chem 261:5858-5865. 


\section{Figure Legends}

Figure 1. Biochemical characterization. A) UV/visible spectra of pure laccases recorded for $1.3 \mathrm{mg}$ protein $/ \mathrm{mL}$. Solid line, PM1L-wt; dashed line, OB-1 mutant; dotted line, OB-1del mutant. B) SDS-PAGE of the purified OB-1 mutant. Lanes: 1, protein ladder; 2, culture filtrate; $3,\left(\mathrm{NH}_{4}\right)_{2} \mathrm{SO}_{4}$ fractional precipitation; 4, anion exchange (HiTraP Q FF); 5, high resolution anion exchange (Biosuite Q). C) MALDITOF mass spectra of purified mutants (PM1L-wt, dashed line; OB-1, solid line). The $\mathrm{pH}$ activity profiles of wild type and mutant laccases for ABTS (D) and DMP (E): black squares, PM1L-wt; white triangles, OB-1 mutant; white circles, OB-1del mutant. Activities were measured in $100 \mathrm{mM}$ Britton and Robinson buffer at different pHs with $3 \mathrm{mM}$ ABTS or DMP as the substrate. Laccase activity was normalized to the optimum activity value and each point (and the corresponding standard deviation) represents the average of three independent experiments. F) Thermostability $\left(\mathrm{T}_{50}\right)$ of PM1L-wt (black squares), the OB1 mutant (white triangles) and the OB1del mutant (white circles). The $\mathrm{T}_{50}$ is defined as the temperature at which the enzyme retains $50 \%$ of its activity after a 10 min incubation. Each point (and the corresponding standard deviation) represents the average of three independent experiments.

Figure 2. Dye decolourization by the laccase mediator system. The oxidation of high redox potential dyes was analyzed for the OB-1 mutant (A) and TvL (B) in the presence or absence of redox mediators. The percentage decolourization was measured after 21 hours at room temperature in a reaction mixture containing 0.01 $\mathrm{U}$ of laccase, with or without $1 \mathrm{mM}$ of redox mediator (HBT or acetosiringone). The initial dye concentrations were $0.015,0.0075$ and $0.002 \%$ for PolyR478, RB5 and Azure B, respectively (resulting in an initial absorbance at the corresponding wavelength of 1.2). Decolourization was monitored at 520, 598 and $647 \mathrm{~nm}$ for 
PolyR478, RB5 and Azure B, respectively, and the data points represent the average of measurements performed in triplicate with a SD $10 \%$ of the mean.

Figure 3. Spectro-electrochemical characterization. The $\mathrm{E}^{\mathrm{o}} \mathrm{T} 1 \mathrm{Cu}$ for $\mathrm{PM} 1 \mathrm{~L}-\mathrm{wt}$ (A) and the OB-1 mutant (B) was assessed by mediated redox reductive titration. Current densities of $+400,+450,+500,+550,+600,+650,+700,+750$ and $+850 \mathrm{mV}$ were applied to measure PM1L-wt. Current densities of $+350,+400,+450,+500$, $+550,+600,+650,+700,+750,+800,+850,+900$ and +950 were applied to measure the OB-1. The insert in $\mathbf{A}$ shows a typical Nernst plot of the dependence of the applied potential versus the absorbance at $600 \mathrm{~nm}$ and the averaged parameters calculated from the titrations. C) $\mathrm{O}_{2}$ consumption activity assays with $\mathrm{K}_{4}\left[\mathrm{Fe}(\mathrm{CN})_{6}\right]$ and $\mathrm{K}_{4}\left[\mathrm{Mo}(\mathrm{CN})_{8}\right]$. For $\mathbf{A}$, $\mathbf{B}$ and $\mathbf{C}$, redox titration of the wellcharacterised T. hirsuta laccase (ThL) was also performed as a control. (D) CD spectra analysis. Solid line, PM1L-wt; dashed line, OB-1 mutant; dotted line, OB1del mutant.

Figure 4. The extra N-terminal extension in the OB-1 mutant. A) Alternative processing of the laccase OB-1 proposed in S. cerevisiae. B) Fusion construct without the EAEA cleavage site and the role of KEX2 in mature OB-1del secretion. The a-factor pre-leader is represented in yellow, the a-factor pro-leader in grey and the mature laccase in blue. Blue stars indicate glycosylation sites in the pro-leader.

\section{Figure 5. Generation of the truncated OB-1del mutant by in vivo overlap} extension (IVOE) deletion mutagenesis An autonomously replicating plasmid was generated by designing specific overhangs between fragments containing homologous regions, between which the truncated products were spliced into in the linearized vector. The products from PCR 1 and PCR 2 had overhangs separated by regions of 39, 40 and $66 \mathrm{bp}$ homologous to the linearized vector for in vivo cloning. 
The a-factor pre-leader is represented in violet; the a-factor pro-leader in white; the STE 13 cleavage site in red; the OB-1 gene in yellow, and the shuttle vector in black.

Figure 6. The coordination sphere of the T1 Cu site. Mutations A461T and S426N are highlighted in green in the PM1L-wt (A) and the OB-1 mutant (B). The T1 $\mathrm{Cu}$ for PM1L-wt and the OB1-mutant are represented in cyan blue and yellow, respectively. The residues involved in the coordination of the $\mathrm{T} 1 \mathrm{Cu}$ are represented in blue.

A

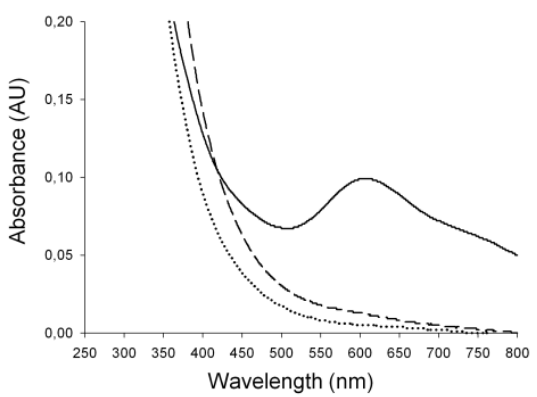

D

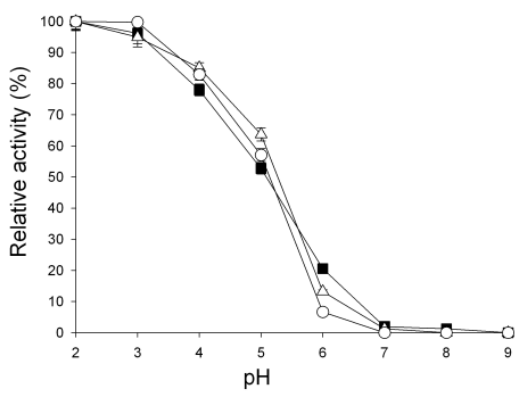

B

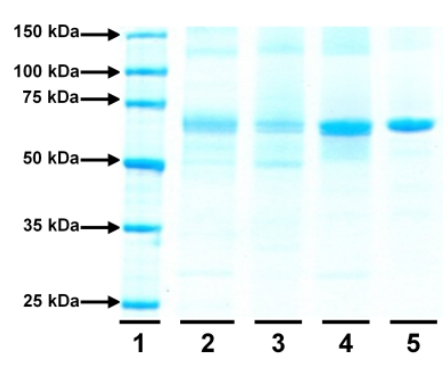

E

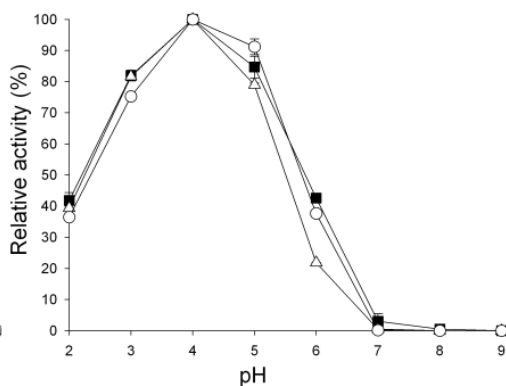

C

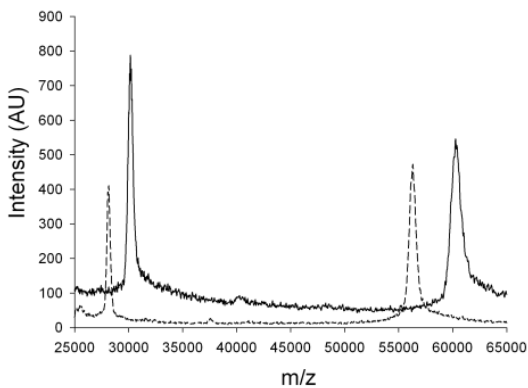

F

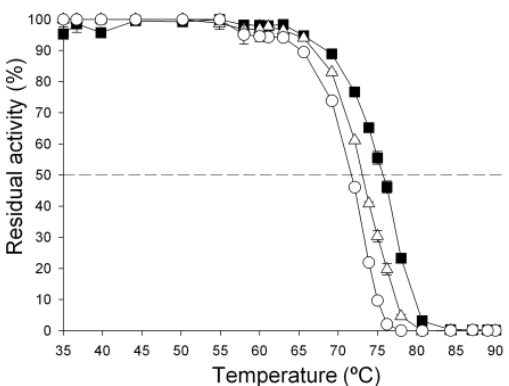

Figure 1 
Fig. 2

A

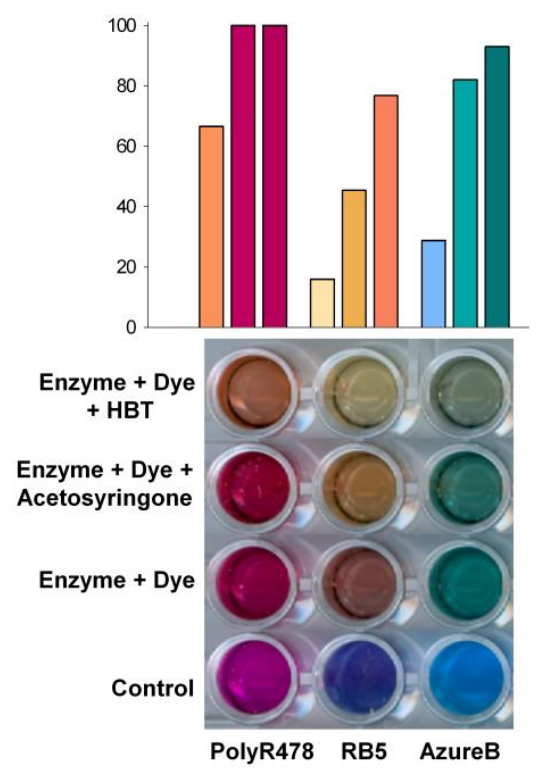

B

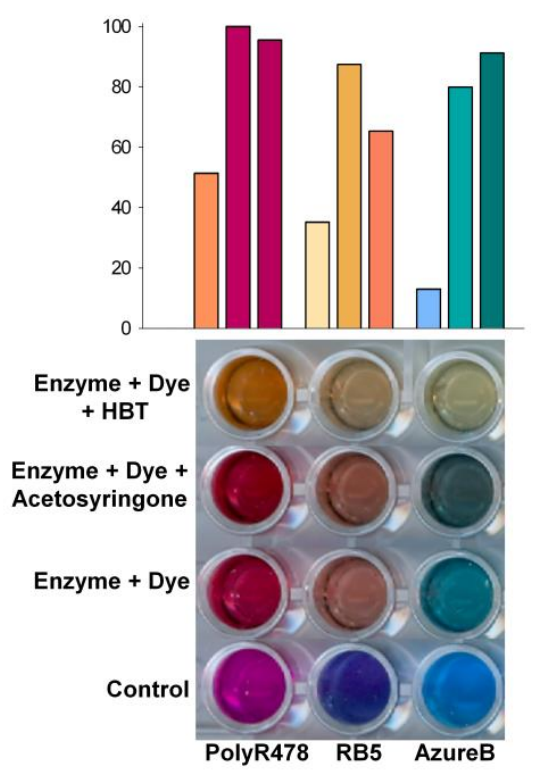

\section{Figure 2}

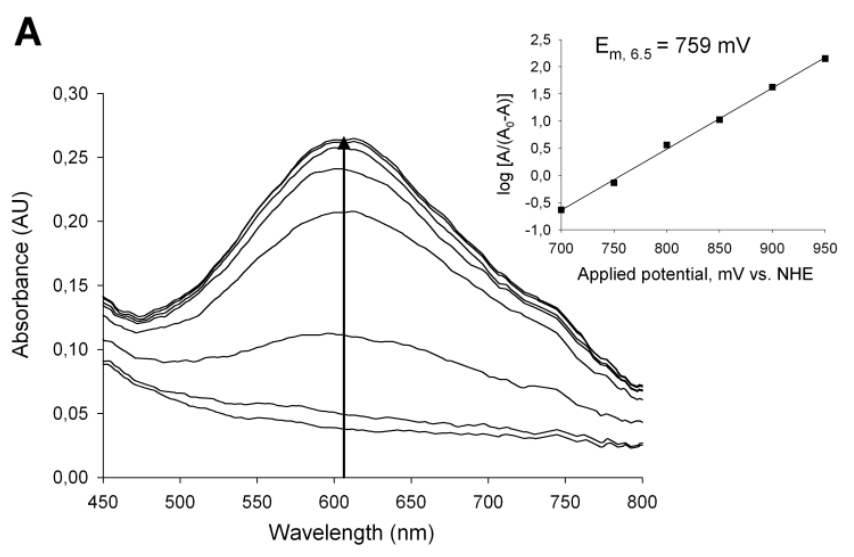

C

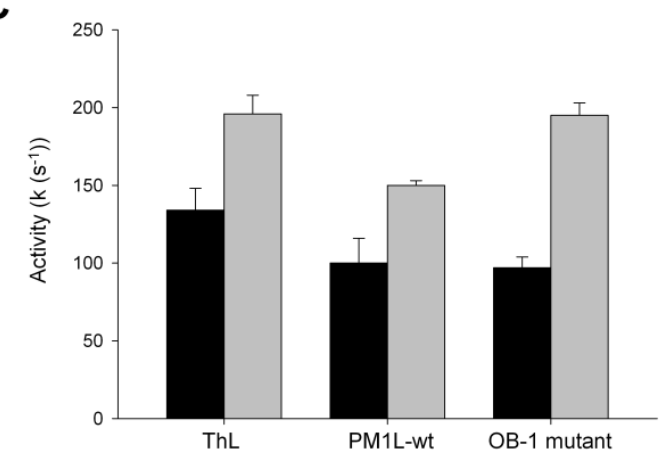

B

Fig. 3

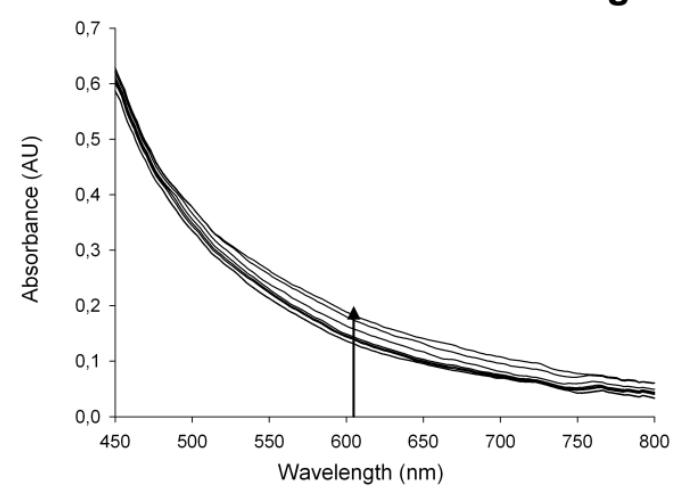

D

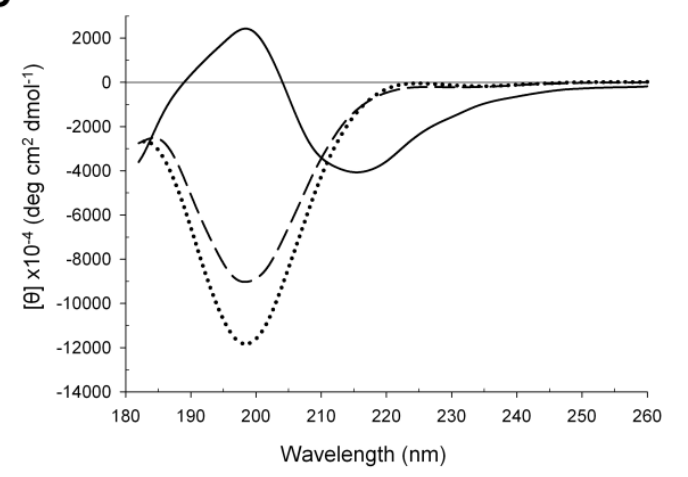

\section{Figure 3}


Fig. 4

A

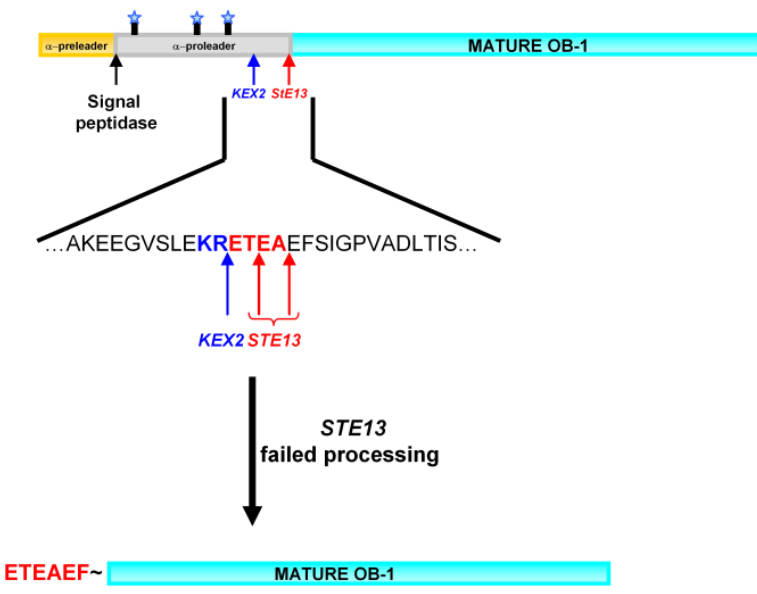

B

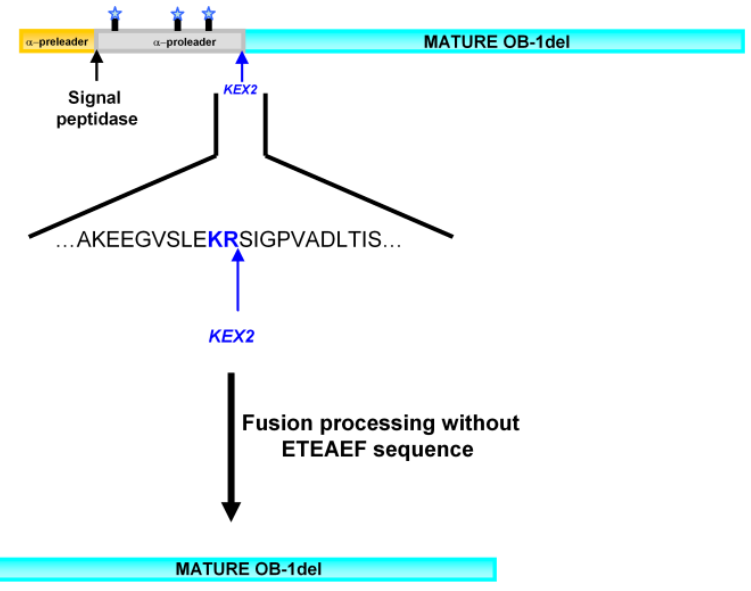

Figure 4 
Fig. 5
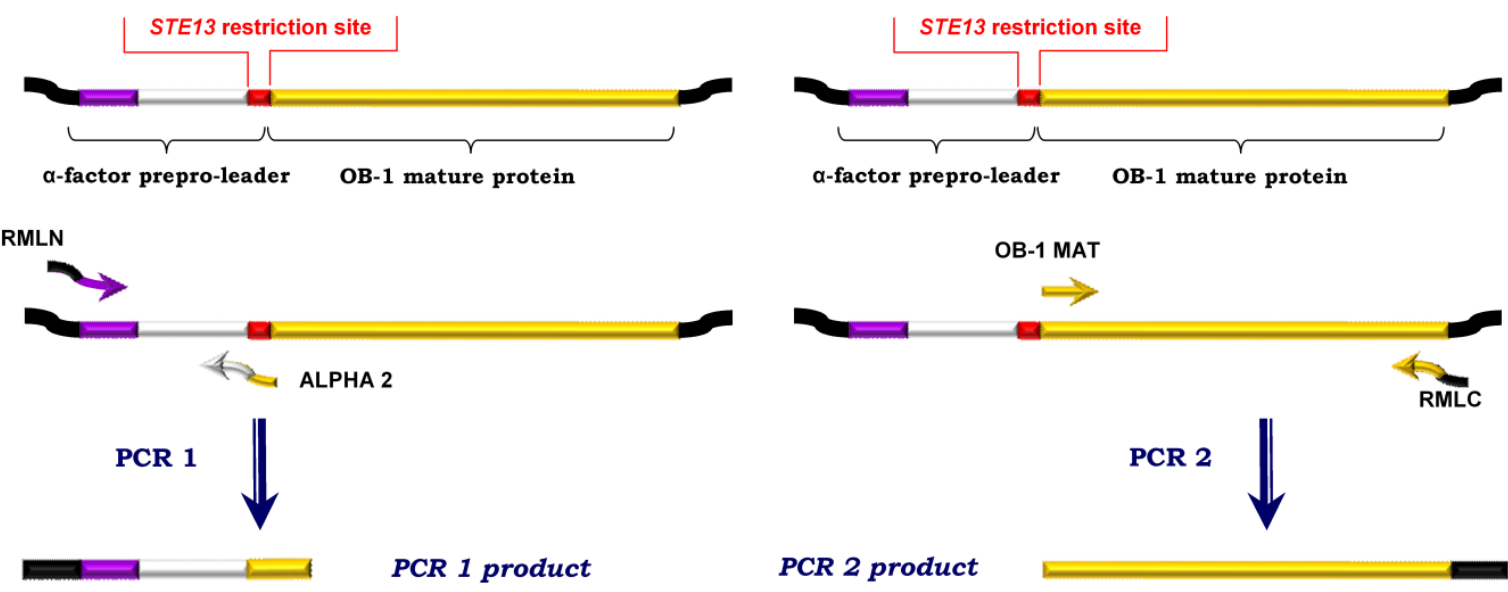

PCR 2

PCR 2 product
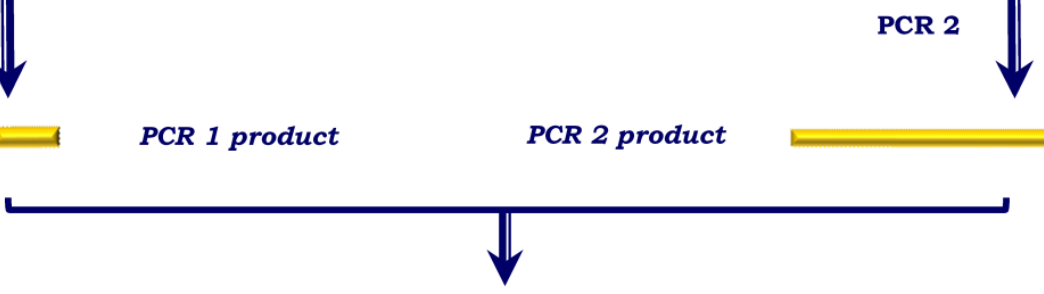

Transformation in S. cerevisiae

'in vivo' DNA recombination

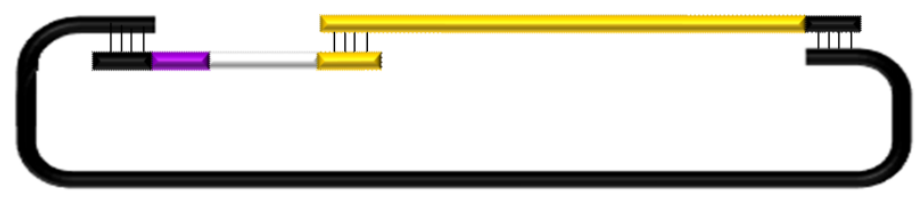

\section{Figure 5}


A

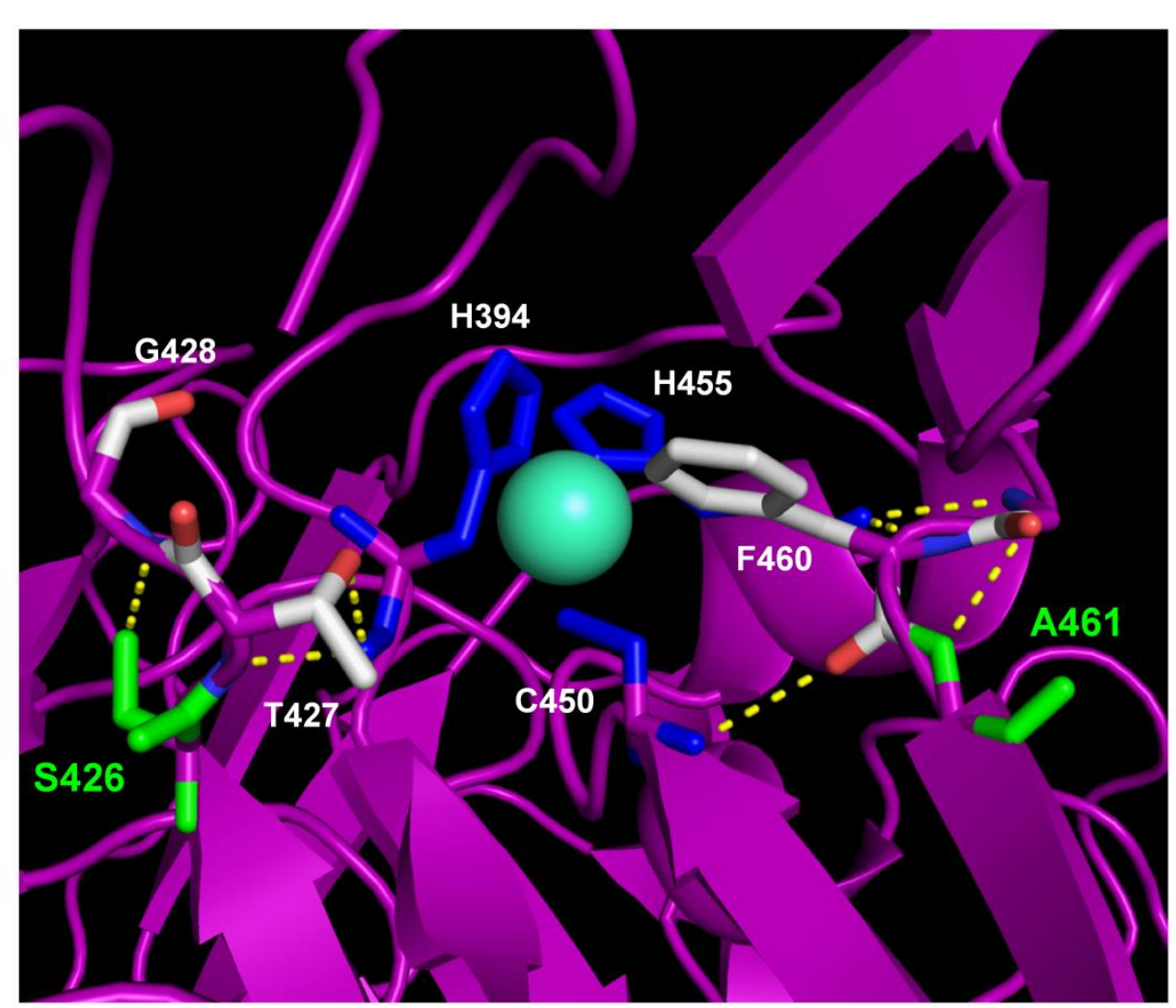

Fig. 6

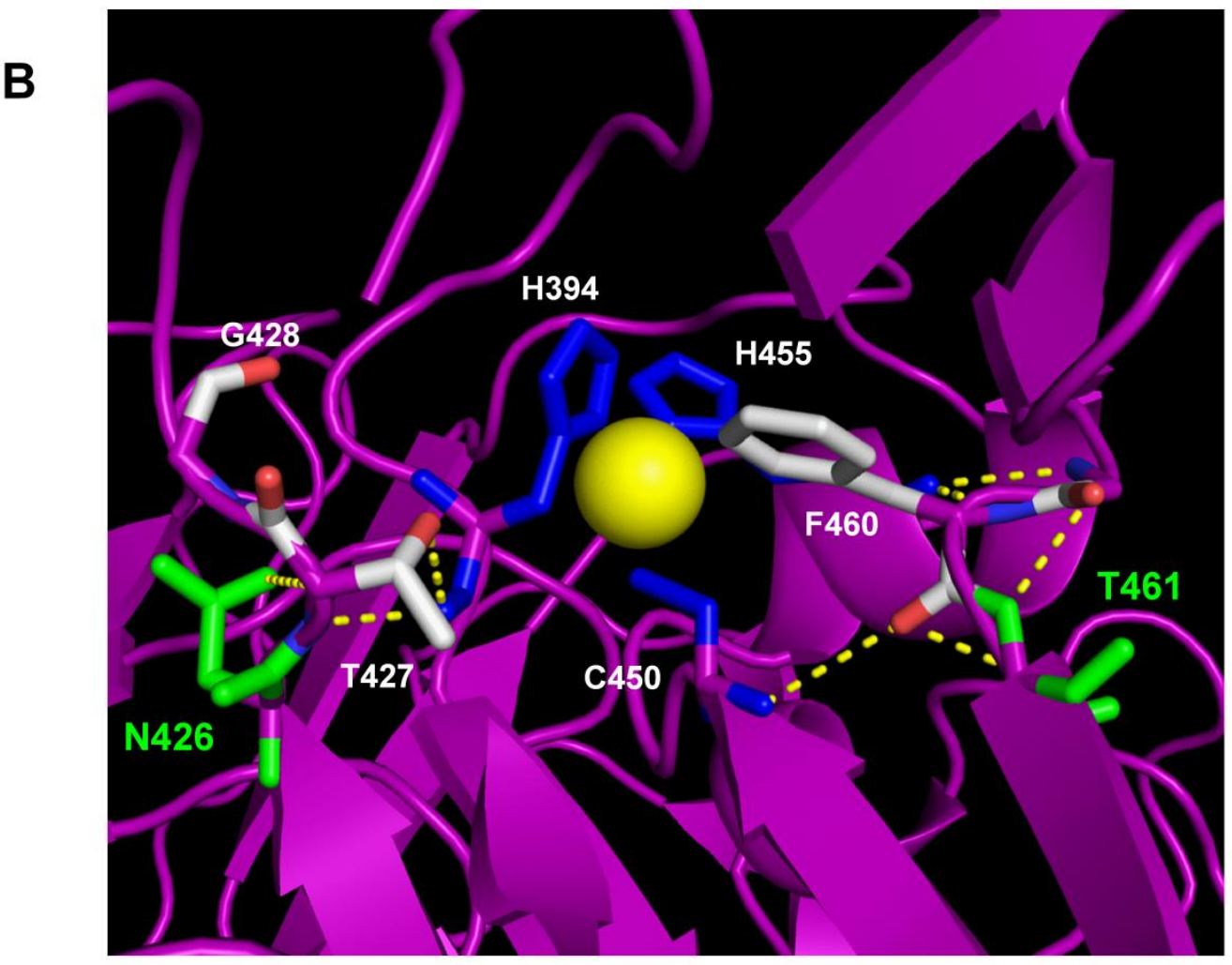

Figure 6 


\section{Tables}

Table 1. Biochemical and spectrochemical features of PM1L-wt and the PM1 mutants.

\begin{tabular}{|c|c|c|c|}
\hline Characteristics & PM1L-wt & OB-1 & OB-1del \\
\hline $\mathrm{MW}^{1}$ & 53,219 & 53,991 & 53,284 \\
\hline $\mathrm{MW}^{2}$ & 56,290 & 60,310 & n.d. \\
\hline Glycosylation (\%) & 6 & 12 & 12 \\
\hline Thermal stability, $\mathrm{T}_{50}\left({ }^{\circ} \mathrm{C}\right)$ & $76.3^{\circ} \mathrm{C}$ & $73.1^{\circ} \mathrm{C}$ & $71.7^{\circ} \mathrm{C}$ \\
\hline $\mathrm{pI}$ & 5.4 & 5.1 & 5.3 \\
\hline Optimum pH (with ABTS) & 3 & 3 & 3 \\
\hline Optimum pH (with DMP) & 4 & 4 & 4 \\
\hline$\left(A_{280} / A_{610}\right)$ & 25.3 & 82.8 & 160.6 \\
\hline $\mathrm{E}^{\mathrm{o}-\mathrm{T}} 1 \mathrm{Cu}(\mathrm{mV})$ & 759 & n.m. & n.m. \\
\hline $\mathrm{CD}$ spectra (minimum, $\mathrm{nm}$ ) & 215 & 207 & 216 \\
\hline $\mathrm{N}$-terminal end & SIGP & ETEAEFSIGP & SIGP \\
\hline
\end{tabular}

${ }^{1}$ Estimated from the amino acid composition; ${ }^{2}$ estimated by MALDI-TOF mass spectrometry; n.d. not determined; n.m. non-measurable. The extra N-terminal extension is highlighted in bold. 
Table 2. Purification of the OB-1 mutant.

\begin{tabular}{|c|c|c|c|c|c|c|}
\hline Purification Step & Vol (mL) & $\begin{array}{c}\text { Volumetric Activity } \\
{[\mathrm{U} / \mathrm{mL}]}\end{array}$ & $\begin{array}{l}\text { Protein } \\
{[\mathrm{mg} / \mathrm{mL}]}\end{array}$ & $\begin{array}{c}\text { Specific Activity } \\
{[\mathrm{U} / \mathrm{mg}]}\end{array}$ & $\begin{array}{c}\text { Activity Yield } \\
(\%)\end{array}$ & $\begin{array}{l}\text { Purification } \\
\text { factor }\end{array}$ \\
\hline Culture filtrate & 1815 & 0.99 & 0.26 & 3.8 & 100 & --- \\
\hline $\begin{array}{l}\text { Fractional } \\
\text { precipitation }\end{array}$ & 29 & 62 & 5.04 & 12.3 & 100 & 3.2 \\
\hline HiTraP-QFF & 11 & 127 & 2.52 & 50.4 & 78 & 13.2 \\
\hline $\begin{array}{l}\text { High resolution } \\
\text { Biosuite } Q\end{array}$ & 1.0 & 606 & 1.38 & 439 & 34 & 115 \\
\hline
\end{tabular}


Table 3. Comparison of the kinetic parameters of PM1 mutants expressed in S. cerevisiae and wild type PM1 expressed in fungus.

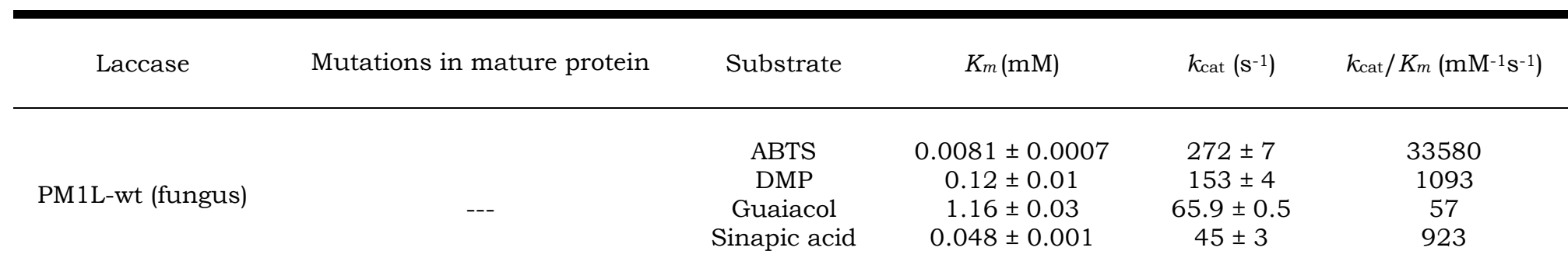

$\begin{array}{cccccc} & & & & \\ & & \text { ABTS* } & 0.0063 \pm 0.0009 & 185 \pm 6 & 29365 \\ \text { OB-1 mutant } & \text { V162A, H208Y, S224G, A239P, } & \text { DMP* } & 0.14 \pm 0.02 & 125 \pm 4 & 893 \\ & \text { D281E, S426N, S454F, A461T } & \text { Guaiacol* } & 6.6 \pm 0.5 & 44 \pm 1 & 17 \\ & & \text { Sinapic acid } & 0.073 \pm 0.002 & 129 \pm 9 & \\ & & & & & \\ & \text { V162A, H208Y, S224G, A239P, } & \text { ABTS } & 0.006 \pm 0.001 & 134 \pm 6 & 23124 \\ \text { OB-1del } & \text { D281E, S426N, S454F, A461T } & \text { DMP } & 0.16 \pm 0.01 & 49 \pm 1 & 311 \\ & \text { (N-TERMINAL EXTENSION } & \text { Guaiacol } & 3.8 \pm 0.3 & 21.2 \pm 0.5 & 5.6 \\ & \text {-ETEAEF- DELETED) } & \text { Sinapic acid } & 0.074 \pm 0.002 & 56 \pm 6 & 757\end{array}$

*Data from Mate et al. 2010. 
Table 4. $C D$ analysis.

\begin{tabular}{|c|c|c|c|c|c|c|}
\hline Laccase & a-helix & $30^{-}$helix & $\beta$-sheet & $\beta$-turns & Unordered & $\sum$ \\
\hline $\begin{array}{c}\text { X-ray of laccase from } \\
\text { Coprinus cinereus (PDB } \\
1 \mathrm{HFU})\end{array}$ & 0.08 & 0.04 & 0.38 & 0.12 & 0.38 & 1.00 \\
\hline PM1L-wt & 0.04 & 0.03 & 0.41 & 0.12 & 0.38 & 0.98 \\
\hline OB-1 mutant & 0 & 0.05 & 0.37 & 0.1 & 0.47 & 0.99 \\
\hline OB-1del mutant & 0.02 & 0.05 & 0.36 & 0.1 & 0.48 & 1.01 \\
\hline RMS deviation ${ }^{*}$ & 0.030 & 0.025 & 0.043 & 0.032 & 0.038 & --- \\
\hline
\end{tabular}

*RMS deviation for set of $25 \beta$-proteins used for calculations of secondary structures based on CD spectra. 